\title{
Potential sources of mouth drying in beverages fortified with dairy proteins: A comparison of casein- and whey-rich ingredients
}

\author{
C. A. Withers, ${ }^{*}$ M. J. Lewis, ${ }^{\star}$ M. A. Gosney, $† \ddagger$ and L. Methven ${ }^{\star 1}$ \\ *Department of Food and Nutritional Sciences, University of Reading, Reading, RG6 6AP, United Kingdom \\ †Clinical Health Sciences, University of Reading, Reading, RG1 5AQ, United Kingdom \\ $\ddagger$ The Royal Berkshire NHS Trust, Reading, RG1 5AN, United Kingdom
}

\section{ABSTRACT}

Oral nutritional supplement drinks (ONS) are beverages high in dairy proteins that are prescribed to individuals at risk of malnutrition. Consumption of ONS is poor in elderly care facilities, with patients commenting that the sensory attributes of these drinks reduce their enjoyment and willingness to consume. Mouth drying is an attribute of ONS found to build with repeated consumption, which may further limit liking of these products. This study investigated the sources of drying sensations by sequential profiling, with a trained sensory panel rating a range of model milk systems and ONS over repeated sips and during after-effects. Sequential profiling found that fortification of milk with both caseinate and whey protein concentrate significantly increased the perception of mouth drying over repeated consumption, increasing by between 35 and $85 \%$ over consumption of $40 \mathrm{~mL}$. Enrichment of ONS with either whey protein concentrate or milk protein concentrate to a total protein content of $8.7 \%$ (wt/wt) resulted in whey and casein levels of 4.3:4.4\% and 1.7:7.0\% respectively. The product higher in whey protein was substantially more mouth drying, implying that whey proteins may be the most important contributor to mouth drying in ONS. However, efforts to mask mouth drying of protein-fortified milk by increasing sweetness or fat level were unsuccessful at the levels tested. Increasing the viscosity of protein-fortified milk led to a small but significant reduction in mouth drying. However, this approach was not successful when tested within complete ONS. Further analysis is required into the mechanism of protein-derived mouth drying to mask negative sensations and improve the enjoyment and consumption of protein-rich ONS.

Key words: dairy protein, mouth drying, astringency, masking

Received July 21, 2013.

Accepted November 15, 2013.

${ }^{1}$ Corresponding author: l.methven@reading.ac.uk

\section{INTRODUCTION}

Mouth drying of dairy products has had little investigation. The terms "mouth drying" and "astringency" are often used synonymously, and yet the term "astringency" itself is often considered to cover a range of sensations, as reviewed recently by Bajec and Pickering (2008). The definition of astringency given by the American Society for Testing and Materials (ASTM, 2004) is "the complex of sensations due to shrinking, drawing or puckering of the epithelium as a result of exposure to substances such as alums or tannins." Bajec and Pickering (2008) noted that the literature concerning astringency remains unclear in deciding whether it is best regarded as a single perceptual phenomenon or as a compound term encompassing several different tactile sensations. In general, most astringents are thought to reduce the lubrication ability of saliva in the mouth by interacting with mucopolysaccharides and precipitating salivary proteins (Lyman and Green, 1990; Lemieux and Simard, 1994; Smith and Noble, 1998). The late onset of perceived astringency occurs as the mucous membranes shrink, and true astringents, such as polyphenolic tannins in wine, tea, and soymilk, bind proline-rich salivary proteins, which elicit the characteristic mouth puckering effect. Although tannins are generally the cause of astringent sensations in most beverages, the mouth-drying properties found in milk and oral nutritional supplements (ONS) must originate from alternative sources (Hagerman and Butler, 1981; Chien and Snyder, 1983; Ireland et al., 1986). The exact nature and mechanism of the drying sensation from dairy products is uncertain, and may not be the same as true astringency, as defined above; therefore; terming the sensation "mouth drying" is considered more appropriate in this paper when discussing dairy-based beverages.

Two possible protein sources of mouth drying exist in dairy drinks: the whey proteins, implicated as early as 1967 (Josephson et al., 1967), and the caseins (Harwalkar et al., 1993). As noted by previous authors, whey protein beverages are manufactured at either low 
or neutral pH (Beecher et al., 2008), and the low-pH beverages have been shown to be particularly astringent (Sano et al., 2005; Beecher et al., 2008; Kelly et al., 2010). It has been suggested that, at low $\mathrm{pH}, \beta$-LG, a major component of whey protein, contributes directly to mouth drying by precipitating within the oral cavity (Sano et al., 2005), interacting with salivary proteins (Beecher et al., 2008; Ye et al., 2011), or binding to buccal cells (Ye et al., 2012). However, many dairy beverages are not acidic in nature, and the influence of whey proteins may be limited when mouth drying is noted in this type of beverage (Methven et al., 2010). However, the intensive heat treatment of UHT-produced, neutral$\mathrm{pH}$ dairy beverages could involve the denaturation of $\beta$-LG, which may form precipitants before consumption that could give a mouth-drying effect.

Alternatively, the formation of $\beta-\mathrm{CN}$ breakdown products $(\gamma-\mathrm{CN})$ by proteolysis has been proposed to lead to mouth drying (Josephson et al., 1967; Harwalkar et al., 1993). Proteolysis-based mouth drying, however, is heat resistant, as enzymes produced by Pseudomonas species and the indigenous enzyme plasmin can withstand high temperatures and act on $\beta$-CN to yield mouth-drying $\gamma$-caseins (Harwalkar, 1972; Harwalkar et al., 1993). However, there is minimal presence of these enzymes in milk, producing low concentrations of $\gamma-\mathrm{CN}$; this coupled with the inhibition of plasmin by denatured $\beta$-LG could yield very little casein-based mouth drying. The literature contains few comparisons of these 2 potential sources of mouth drying - whey and casein-in milk-based beverages.

Oral nutritional supplement drinks are high-protein beverages that have been shown to elicit mouth drying. They are typically long-shelf-life products that are often UHT treated, and the high protein is usually achieved through the inclusion of dairy proteins. The drinks are prescribed to patients at risk of malnutrition; for example, on elderly care wards, in nursing homes, or in the community, but are poorly consumed and frequently wasted (Gosney, 2003). These ONS products have been found to build in mouth drying with repeated consumption (Methven et al., 2010), which can easily be perceived by older adults; in some cases, mouth drying perception may be enhanced with age (Withers et al., 2013). Therefore, investigating the sources of ONSbased mouth drying and potential methods to reduce or mask this negative attribute may help to minimize the perception of this characteristic. This in turn could improve liking and consumption of these nutritional beverages by older adults and patients.

Sweetness was found by Lyman and Green (1990) to reduce the perceived astringency of tannic acid solutions, with sucrose being more effective than aspartame. The source of this difference is uncertain, although the authors suggest that sucrose produced greater salivation than aspartame and increased the overall viscosity and lubrication of the samples. It is also possible that the bitterness of the aspartame was confused with astringency, leading to higher ratings overall (Lyman and Green, 1990). Nevertheless, sweetness can help to mask astringency; therefore, adding sucrose should be evaluated as a method to suppress protein-derived mouth drying.

Viscosity is another potential masking ingredient, because enhancing the thickness of beverages has been suggested to reduce astringency (Lyman and Green, 1990). Thickening dairy drinks may help to reduce mouth drying through prevention of interaction between mouth-drying proteins and the oral epithelium. This would coat and shield the mouth from the drying properties of the drink and therefore reduce the total drying sensation. In the current study, enhancing dairy beverage viscosity with a thickening agent was assessed as another potential method of masking ONS mouth drying. However, in a previous study of low-pH whey protein beverages, an almost 5 -fold increase in viscosity was found not to reduce astringency (Beecher et al., 2008).

The addition of lipids to dairy products to enhance oral lubrication may also help to mask mouth drying. Lipids can enhance beverage mouthfeel characteristics by 2 potential parameters. Supplementing lipids into dairy beverages can provide a richer, fuller texture to the drinks (Fillion and Kilcast, 2001), and the addition of solid fats with melting points around body temperature may accentuate this mouthfeel to a greater extent as the lipid melts within the mouth during consumption. The composition of lipid FA could also influence the taste characteristics of fat-enhanced beverages, which may suppress the perception of mouth drying. Rapeseed oil (RSO) is typically used in ONS products and although milk fat (butter) is less frequently used, it is a solid fat and may act to give a familiar dairy richness as the fat melts. Milk fat has a higher melting point, at around body temperature $\left(35-38^{\circ} \mathrm{C}\right)$, compared with the lower melting point of $\operatorname{RSO}\left(-10^{\circ} \mathrm{C}\right)$, which may influence the perceived texture and mouthfeel of dairy beverages enhanced with milk fat (Early, 1998; Gunstone, 2002). The FA composition of these 2 lipids differ, with milk fat containing more saturated FA such as palmitic, myristic, and stearic acids, whereas RSO has higher proportions of unsaturated FA such as oleic, linoleic, and linolenic acids (Gunstone, 2002; Jensen, 2002). These FA can be detected in the oral cavity by a range of receptors, including G-protein-coupled receptors, delayed rectifying potassium channels, and the fatty acid translocase CD36, which could elicit a taste for each lipid and potentially suppress the mouth-drying 
effect of the protein (Mattes, 2009a,b). Sunflower oil was used in this study because it is similar to RSO and more widely available for smaller bench-scale testing; therefore, preliminary testing with lipid-enriched milk bases used sunflower oil, which does not elicit any additional taste characteristics in the samples.

This investigation aimed to test the following hypotheses: (1) that casein within protein-fortified beverages of neutral pH could contribute to perceived mouth drying, and that this may result from the presence of $\gamma$-CN; (2) that whey proteins within protein-fortified beverages of neutral $\mathrm{pH}$ could contribute to perceived mouth drying; (3) that increased sweetness could suppress the perception of mouth drying from protein-fortified beverages; (4) that increasing viscosity could reduce perceived mouth drying from protein-fortified beverages, perhaps by reducing the interaction between proteins and the oral epithelium; and (5) that increasing fat could reduce perceived mouth drying from protein-fortified beverages, perhaps by increasing lubrication.

\section{MATERIALS AND METHODS}

\section{Sample Preparation for PAGE}

Two commercial ONS products (UHT treated), milk protein concentrate (MPC85; containing 85\% protein), whey protein concentrate (WPC75; containing $75 \%$ wt/wt protein), sodium caseinate (NaCas; containing $85 \% \mathrm{wt} / \mathrm{wt}$ protein), and calcium caseinate (CaCas; containing 85\% wt/wt protein) were all prepared for protein analysis by gel electrophoresis. The MPC, WPC, and caseinates were hydrated to $10 \%$ (wt/wt) with reverse osmosis water at $60^{\circ} \mathrm{C}$ and allowed to fully hydrate at ambient temperature $(24 \pm$ $1^{\circ} \mathrm{C}$ ) for $2 \mathrm{~h}$ before analysis. The protein ingredients were hydrated to $10 \%$ powder in water (wt/wt) to ensure that adequate amounts of casein could produce clear banding on the electrophoretogram, and to be comparable to the protein levels in commercial ONS products, which are typically between 4 and $10 \%$ (wt/ wt). Accounting for the differences in protein content between the ingredients, the final concentrations were $8.5 \%$ (wt/wt) protein in the MPC sample, $7.5 \%$ (wt/ wt) protein in the WPC sample, and $8.5 \%$ (wt/wt) protein in the caseinate samples. Commercial ONS products were added directly to the gel loading well of the electrophoresis plates. Oral nutritional supplement 1 was a low-protein commercial sample composed of $4.2 \%$ (wt/wt) protein entirely from MPC, and ONS 2 contained higher protein levels of $8.7 \%$ (wt/wt), comprising MPC (4.4\% wt/wt), WPC (1.8\% wt/wt), and NaCas $(3.7 \%$ wt/wt).

\section{Gel Electrophoresis}

Urea-PAGE was both conducted on ONS and the milk protein samples. The method was based on techniques used in the analysis of skim milk proteins (Kim and Jimenez-Flores, 1992): $10 \mu \mathrm{L}$ of each sample, in a 1:5 ratio with sample buffer, was boiled for $2 \mathrm{~min}$ and added onto the gel. Urea-PAGE was used for analysis of caseins because these proteins are very hydrophobic and of similar molecular size, and therefore are not effectively resolved by other PAGE methods. The addition of urea acts to further dissociate the proteins, allowing easier separation and greater clarity of the resulting electrophoretograms (Harris and Angal, 1989; Tremblay et al., 2003). The separating gel contained Tris-HCl $(2.63 M)$ and urea $(8 M)$ adjusted to $\mathrm{pH} 8.9$, the stacking gel and the sample buffer contained Tris$\mathrm{HCl}(0.6 M)$ and urea $(8 M)$ adjusted to $\mathrm{pH} 6.7$, and the electrode buffer contained Tris $(0.05 M)$ and glycine $(0.38 \mathrm{M})$. The stacking gel was run at $112 \mathrm{~V}$, which was increased to $224 \mathrm{~V}$ for the separating gel. Following separation, the gel was stained with Coomassie blue and then destained with methanol and acetic acid until the bands were visible (Kim and Jimenez-Flores, 1992).

\section{Sample Preparation for Sequential Profiling}

A range of protein-enriched skim milk samples (UHT-treated long-life skim milk, local retailer) and ONS (UHT treated) were prepared for sequential profiling to assess mouth drying (Table 1). Comparing caseinate types for mouth drying involved rehydrating $\mathrm{NaCas}$ and CaCas (5\% wt/wt) in skim milk at $60^{\circ} \mathrm{C}$, with sugar $(2 \% \mathrm{wt} / \mathrm{wt})$ added for sample palatability (Table 1, samples 1 and 2). To compare mouth drying of caseinates and whey, WPC and NaCas (5\% wt/wt) were rehydrated in skim milk with additional lactose added to the NaCas sample and a starch thickener $(0.4 \% \mathrm{wt} / \mathrm{wt}$, a commercial modified maize starch, cold water soluble; Thick and Easy, Fresenius Kabi, Runcorn, UK) added to the WPC sample to balance sweetness and viscosity (Table 1, samples 2 and 3 ). The mouth-drying characteristics of ONS were assessed in the sequential profiling of 3 unflavored ONS products, 1 standard protein blend, 1 WPC-enriched ONS, and 1 ONS modified with all protein originating from MPC (Table 1, samples 4, 5, and 6). Skim milk was enriched with MPC and WPC to establish mouth -drying base samples for drying minimization analysis (Table 1, samples 7 and 8).

All samples were prepared at $60^{\circ} \mathrm{C}$ over $15 \mathrm{~min}$ and thoroughly mixed using an electric whisk, before being allowed to fully hydrate and cool to room temperature $\left(24 \pm 1^{\circ} \mathrm{C}\right)$ for up to $2 \mathrm{~h}$ before use. 
Table 1. Samples prepared for sequential profiling: protein sources ${ }^{1}$ and composition (\% wt/wt)

\begin{tabular}{|c|c|c|c|c|c|c|c|c|c|}
\hline $\begin{array}{l}\text { Sample } \\
\text { number }\end{array}$ & Sample description & MPC85 & $\mathrm{NaCas} 85$ & WPC75 & CaCas85 & $\begin{array}{l}\text { Skim } \\
\text { milk }\end{array}$ & $\begin{array}{l}\text { Total } \\
\text { casein }\end{array}$ & $\begin{array}{l}\text { Total } \\
\text { whey }\end{array}$ & $\begin{array}{l}\text { Total } \\
\text { protein }\end{array}$ \\
\hline 1 & CaCas-enriched milk & - & - & - & 5.0 & 95.0 & 6.8 & 0.6 & 7.4 \\
\hline 2 & NaCas-enriched milk & - & 5.0 & - & - & 95.0 & 6.8 & 0.6 & 7.4 \\
\hline 4 & Standard ONS ${ }^{2}$ & 4.4 & 3.7 & 1.8 & - & - & 6.6 & 2.1 & 8.7 \\
\hline 5 & WPC-modified ONS & 4.4 & 1.5 & 4.45 & - & - & 4.4 & 4.3 & 8.7 \\
\hline 6 & MPC-modified ONS & 9.95 & - & - & - & - & 7.0 & 1.7 & 8.7 \\
\hline 7 & WPC and MPC milk base & 3.0 & - & 8.0 & - & 3.2 & 4.6 & 7.2 & 11.8 \\
\hline 8 & MPC milk base & 10.0 & - & - & - & 3.2 & 9.4 & 2.3 & 11.7 \\
\hline 9 & Starch-enriched base & 3.0 & - & 8.0 & 1.8 & 3.2 & 4.6 & 7.2 & 11.8 \\
\hline 10 & SFO-enriched base ${ }^{3}$ & 3.0 & - & 8.0 & 2.0 & 3.2 & 4.6 & 7.2 & 11.8 \\
\hline 11 & Milk fat-enriched base & 3.0 & - & 8.0 & 2.0 & 3.2 & 4.6 & 7.2 & 11.8 \\
\hline 12 & Sucrose-enriched base & 3.0 & - & 8.0 & 3.0 & 3.2 & 4.6 & 7.2 & 11.8 \\
\hline
\end{tabular}

${ }^{1} \mathrm{MPC} 85=$ milk protein concentrate with $85 \%$ protein; NaCas $85=$ sodium caseinate with $85 \%$ protein; WPC75 = whey protein concentrate with $75 \%$ protein; CaCas $85=$ calcium caseinate with $85 \%$ protein.

${ }^{2} \mathrm{ONS}=$ oral nutritional supplement. Only the protein composition is shown; protein powders were dissolved with other ingredients in water following the typical production process.

${ }^{3} \mathrm{SFO}=$ sunflower oil.

\section{Preparation of Samples to Investigate Masking of Mouth Drying}

Viscosity Samples. To determine the effect of viscosity on mouth drying, the mouth-drying base was enhanced with the starch thickener (see above). The starch thickener $(1.8 \% \mathrm{wt} / \mathrm{wt})$ was added to the mouthdrying base (post-heating) and to the ONS at room temperature. The samples were stirred briskly with a hand whisk for $1 \mathrm{~min}$ and allowed to fully hydrate for 30 min before sensory testing and viscosity measurement at a shear rate of $44.08 \mathrm{~s}^{-1}$ (Haake Viscotester 550, Spindle III, Thermo Scientific, Loughborough, UK). The shear rate was chosen to approximate the oral shear rate, which is typically $50 \mathrm{~s}^{-1}$ (Wood, 1968). Viscosities of such non-Newtonian fluids are measured and quoted at this shear rate to comply with the guidelines of the National Dysphagia Diet Task Force (NDDTF, 2002) of the American Dietetic Association, and are quoted on starch-based dysphagia products commercially available in the United Kingdom and the United States.

Sweet Samples. The mouth-drying base was enriched with sucrose $(3 \% \mathrm{wt} / \mathrm{wt})$ to determine the effects of sweetness on perceived mouth drying. Sucrose was added to protein powders before adding them to the skim milk. The sweetened samples were then heated, mixed, and cooled to ensure the same process as standard base preparation.

Lipid Samples. Sunflower oil (SFO) and milk fat were used to increase the lipid content of the base (approximately $0.1 \%$ in skim milk). Two percent (wt/wt) of each lipid source was added to the hydrated base at $60^{\circ} \mathrm{C}$ and mixed vigorously with an electric hand whisk. The samples were held at temperature for 15 min before cooling over $2 \mathrm{~h}$ to room temperature and being mixed and served immediately.

\section{pH Measurement}

The $\mathrm{pH}$ values of all samples were determined using a digital micro-pH meter (Randox, Crumlin, UK), which was calibrated at $\mathrm{pH} 7$ and 4 before sample testing (slope $>95 \%$ ).

\section{Sequential Profiling}

A trained sensory panel of up to 12 adults (3 male, 9 female; age range 22-59 yr, mean age $39 \mathrm{yr}$ ) expert in profiling techniques, with more than 6 mo of experience each, assessed the samples. The sequential profiling was carried out over a period of time, where a minimum of 2 samples were compared in any specific sample set/ period of time (not every single panelist was present at every single session). The panel characterized 5 specific sensory attributes (sweet, metallic, chalky, mouth coating, and mouth drying) in a sequential profile to determine whether perception of these characteristics increased over time with repeated consumption. Sequential profiling was chosen over time intensity profiling to characterize more than 2 attributes at once, and over temporal dominance methods, because attributes of secondary rather than primary dominance might be important determinants of product liking. The profiling was carried out under the same environmental condi- 
tions as quantitative descriptive analysis (QDA), with panelists tasting 8 consecutive aliquots $(5 \mathrm{~mL})$ of each sample, after which they were instructed to score the 5 attributes following each tasting. Panelists were also instructed to score the same 5 attributes as after-effects, twice, following 30 -s and 60-s time delays, with a 2 -min time delay enforced between sample sets for each of the 8 tastings. The samples were presented in a balanced presentation order, with each assessor testing all products, and 2 products presented per day. The panelists were instructed to consume the entire 5-mL sample; the total volume of each sample consumed during sequential profiling was $40 \mathrm{~mL}$. Samples were presented in transparent plastic cups with random 3-digit numbers for each sample; therefore, panelists were not blinded to the sequential nature of profiling sessions. Warm, still water $\left(40 \pm 3^{\circ} \mathrm{C}\right)$ and crackers were provided to cleanse the palate between products for both sensory trials, but not between shots of the same product during profiling.

The panelists were trained in attribute understanding, using key standards. Sweet taste was described as the taste of sucrose, metallic taste was described as the taste of iron sulfate $(0.003 \mathrm{M})$, chalky mouth-feel was described as the feeling of anti-heartburn medication (Gaviscon, Reckitt Benckiser, Kingston-upon-Thames, UK), mouth coating was the sensation of a film covering the oral cavity, and mouth-drying sensation was compared with the drying sensation typically elicited by the consumption of heat-treated rennet whey. The latter standard was prepared by the coagulation of skim milk with chymosin to product rennet whey, which was then heat treated to $70^{\circ} \mathrm{C}$ for $1 \mathrm{~min}$ and allowed to cool to room temperature before use as a mouth-drying standard for the sensory panel, as previously recommended by Josephson et al. (1967).

All sensory data were collected on acquisition computer software (Compusense Five, version 5, Compusense Inc., Guelph, ON, Canada) using unstructured 15-mm line scales (results scaled from 0 to 100) and consensus anchor words.

\section{Statistical Analysis}

The XLStat software package (version 2009.4.02; AddinSoft, Paris, France) was used to carry out multifactor repeated-measures ANOVA for the comparisons of this sequential profiling data, with assessor, consumption time points, and sample type as 3 treatment effects. Time was used as the repeated measure.

\section{RESULTS AND DISCUSSION}

The $\mathrm{pH}$ values of all samples were within a narrow range of 6.59 and 6.65 ; hence, the discussion considers all samples to be protein-fortified beverages that were of near-neutral $\mathrm{pH}$.

\section{Presence of $y-C N$ in ONS and Ingredients by PAGE}

Urea-PAGE was used to separate the different types of casein. The electrophoretogram demonstrated that, in addition to the more dominant $\alpha$ - and $\beta-\mathrm{CN}, \gamma-\mathrm{CN}$ were also present in ONS, MPC, and caseinate samples, with the individual ingredients providing much stronger $\gamma$-CN banding than the complete supplement drinks (Figure 1). The undefined banding in the ONS samples could result from the interaction of the target proteins with other ONS ingredients; for example, the minerals within the ONS could affect protein structure and stability and the caseins could adsorb onto oil droplet surfaces (Srinivasan et al., 1999). The $10 \%$ caseinates were also shown to contain the highest concentration of $\gamma$-CN, as expected in these pure casein protein ingredients.

Overall, the concentration of $\gamma$-CN was extremely low in all samples, especially compared with the concentration of other proteins, and with no clear defined bands in the ONS. One reason for the poor band definition for $\gamma$-CN could be that there are $3 \gamma$-casein types $\left(\gamma_{1}, \gamma_{2}\right.$, and $\gamma_{3}$ ), each corresponding to 3 different fragments of $\beta-\mathrm{CN}$ depending on the exact plasmin cleavage (Farrell et al., 2004). Previous research indicated that 2 of the 3 casein types result in mouth drying (Harwalkar et al., 1993); therefore, we considered it unnecessary to confirm which $\gamma$-CN types were present when overall levels were apparently low. Although only minimal $\gamma$-CN may be required to elicit mouth-drying effects, these electrophoretograms cast doubt on the role of $\gamma-\mathrm{CN}$ as a source of dairy-based mouth drying in these specific

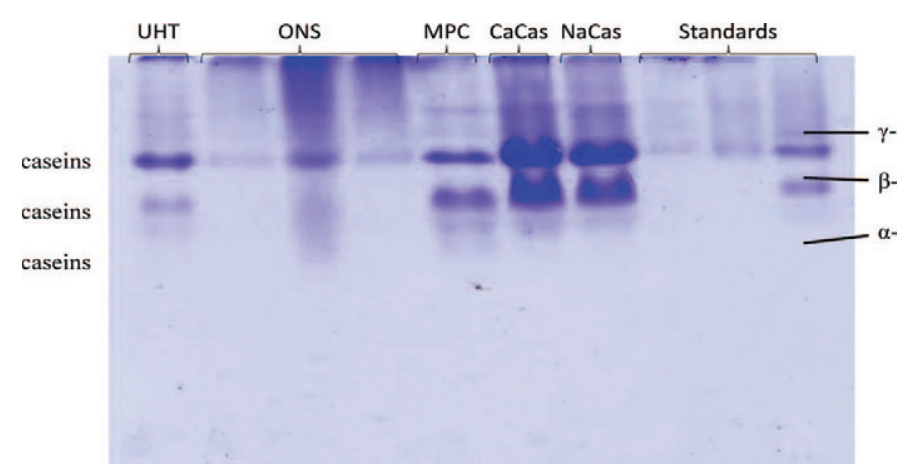

Figure 1. Urea-PAGE electrophoretogram separating the proteins within a range of oral nutritional supplement (ONS) and ingredients. Lane $1=$ UHT milk, lanes 2 to $4=3$ commercial ONS samples, lane $5=$ milk protein concentrate $(\mathrm{MPC} ; 10 \%)$, lane $6=$ calcium caseinate $(\mathrm{CaCas} ; 10 \%)$, lane $7=$ sodium caseinate $($ NaCas; $10 \%)$, lanes 8 and 9 $=\gamma-\mathrm{CN}$ standard, lane $10=\alpha-, \beta-$, and $\gamma$-CN standard. Color version available in the online PDF. 
dairy-based products. However, further sensory analysis into the mouth-drying perceptions of casein- and wheyrich dairy beverages would help us fully understand the role of each ONS ingredient.

\section{Mouth-Drying Comparison of Caseinates in Simplified Skim Milk Systems}

Sequential profiling of caseinates in skim milk was conducted to determine the role of caseins in ONS mouth drying. Although sweetness, mouth coating, and metallic attributes were also sequentially profiled, this study aimed to investigate the role of mouth drying and chalky attributes in dairy systems and ONS. Mouth drying of caseinates was assessed in a simplified milk system enriched with CaCas and NaCas (Table 1, samples 1 and 2). Sequential profiling found NaCas- and CaCas-enriched milks to be significantly different for mouth drying, with mouth drying increasing in both by 85 and $45 \%$, respectively, over time (Figure 2).

When comparing the overall mouth-drying profiles of the caseinate samples, CaCas was found to be significantly more mouth drying than NaCas in skim milk $(P<0.001)$. This correlated with CaCas eliciting a significantly chalkier $(P<0.001)$ particulate texture (Figure 2 and Table 2). Although the panel was trained and understood the difference between chalkiness and mouth drying, the level of chalkiness in the product was higher in CaCas, which may have contributed to the difference in mouth-drying sensation. This extreme chalkiness could originate from the particulate structure of CaCas in solution and possible interactions with the oral cavity.

These findings suggest that mouth drying is dependent upon the type of caseinate. The physical properties of caseinates could help to explain this difference in perception, because $\mathrm{CaCas}$ and $\mathrm{NaCas}$ are very different in appearance and physical properties. In caseinate manufacture, skim milk is treated with acid to precipitate the casein, which destroys the micellar structure through removal of the calcium. To neutralize the curd, either sodium or calcium hydroxide is added, and the latter leads to partial restoration of the micellar structure. Therefore, rehydrated sodium caseinates are mainly translucent and colloidal, whereas rehydrated calcium caseinates are opaque and lower in viscosity (DMV, 2011). Although mouth drying was higher in CaCas and could be a potential cause of mouth drying in ONS, NaCas is the typical protein powder used in these products. Therefore, the ingredient with lower mouth-drying is already in use in standard ONS beverages. Comparing the milk that contained $5 \%$ (wt/wt) NaCas (Figure 2) to the standard ONS, which contained less NaCas $(3.7 \%$ wt/wt; Figure 7$)$, it is clear

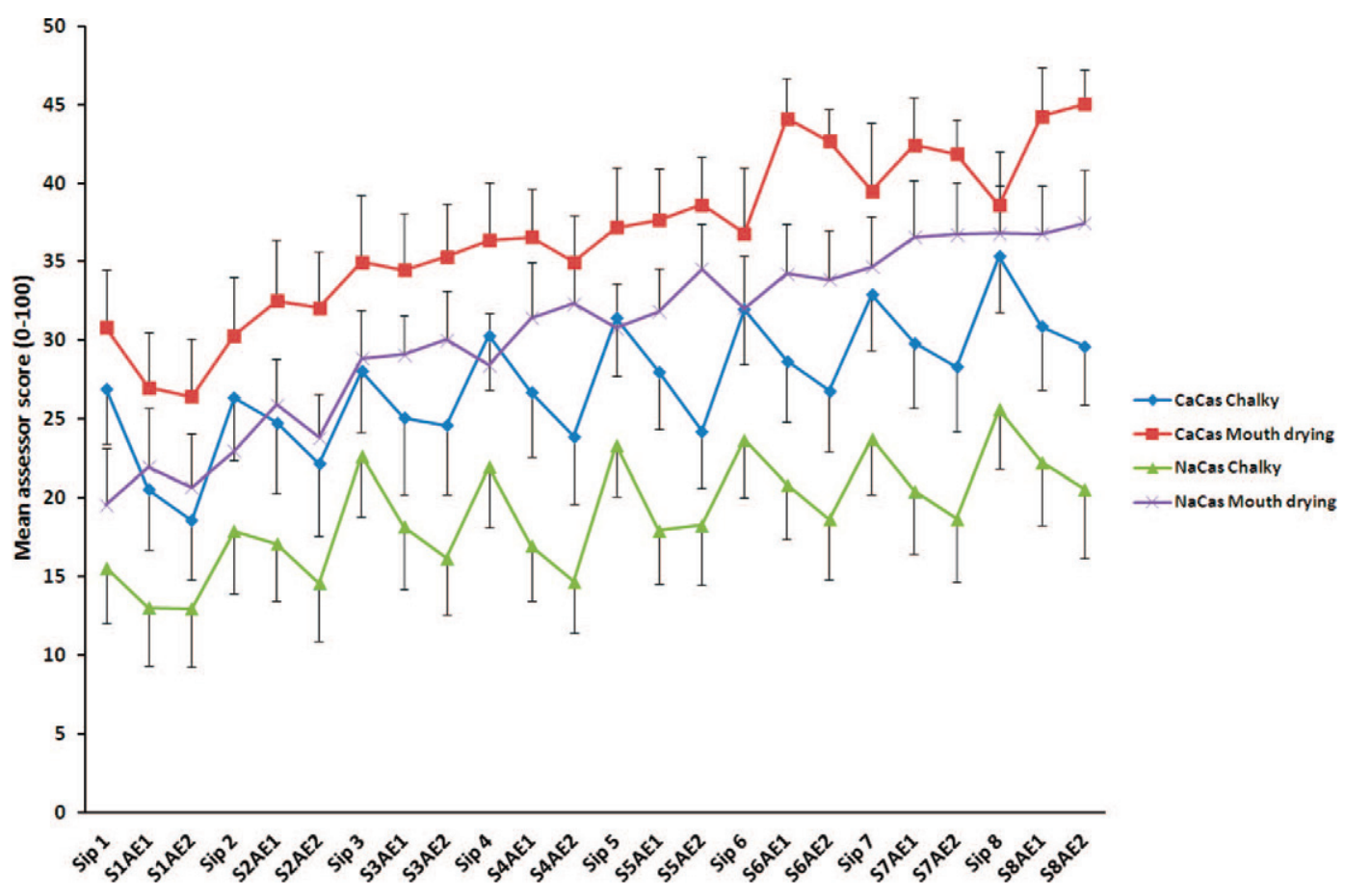

Figure 2. Mouth drying and chalky sequential profile for calcium (CaCas) and sodium caseinate (NaCas) in skim milk. Values shown are assessor mean scores \pm SEM, with each numbered sip (Sip 1 to Sip 8) and corresponding after-effects (e.g., S1AE1 = sip 1 after-effect 1 ). Color version available in the online PDF. 
Table 2. Significances of sequential profiling attributes over time and between samples

\begin{tabular}{|c|c|c|c|c|c|c|c|c|c|c|c|c|}
\hline \multirow[b]{2}{*}{$\begin{array}{l}\text { Sample } \\
\text { Number }\end{array}$} & \multirow[b]{2}{*}{ Sample description ${ }^{2}$} & \multicolumn{10}{|c|}{ Significant difference in mouth drying over time ${ }^{3}$} & \multirow{2}{*}{$\begin{array}{c}\text { Significance } \\
\text { difference in } \\
\text { mouth drying } \\
\text { between samples }\end{array}$} \\
\hline & & Sweet & $\mathrm{R}^{2}$ & Metallic & $\mathrm{R}^{2}$ & Chalky & $\mathrm{R}^{2}$ & $\begin{array}{l}\text { Mouth } \\
\text { coating }\end{array}$ & $\mathrm{R}^{2}$ & $\begin{array}{l}\text { Mouth } \\
\text { drying }\end{array}$ & $\mathrm{R}^{2}$ & \\
\hline 1 & CaCas milk & $*$ & 0.04 & NS & 0.29 & *** & 0.48 & $* *$ & 0.18 & $*$ & 0.85 & $* * *$ \\
\hline 2 & NaCas milk & $* * *$ & 0.01 & $* * *$ & 0.60 & $* * *$ & 0.43 & $* * *$ & 0.35 & $* * *$ & 0.92 & \\
\hline 2 & NaCas (5\%) milk & NS & 0.28 & NS & 0.003 & NS & 0.22 & NS & 0.25 & NS & 0.36 & NS \\
\hline 3 & WPC $(5 \%)$ milk & NS & 0.003 & NS & 0.01 & NS & 0.04 & NS & 0.43 & NS & 0.60 & \\
\hline 4 & Standard ONS & NS & 0.001 & NS & 0.04 & $* *$ & 0.29 & $* * *$ & 0.17 & $* * *$ & 0.66 & $* * *$ \\
\hline 5 & WPC-enriched ONS & NS & & NS & & NS & & NS & & NS & & \\
\hline 4 & Standard ONS & NS & 0.001 & NS & 0.03 & $* *$ & 0.41 & $* * *$ & 0.56 & $* * *$ & 0.69 & NS \\
\hline 6 & MPC-based ONS & $* * *$ & 0.001 & NS & 0.02 & $* *$ & 0.50 & NS & 0.005 & NS & 0.58 & \\
\hline 7 & WPC- and MPC-enriched base & $*$ & 0.02 & NS & 0.08 & NS & 0.15 & $* *$ & 0.23 & * & 0.43 & NS \\
\hline 8 & MPC-enriched base & NS & 0.10 & NS & 0.002 & NS & 0.04 & NS & 0.02 & NS & 0.24 & \\
\hline 7 & Standard base & $* * *$ & 0.13 & NS & 0.01 & NS & 0.19 & $* * *$ & 0.41 & $*$ & 0.45 & ** \\
\hline 9 & Starch-enriched base & NS & 0.02 & NS & 0.05 & NS & 0.28 & NS & 0.04 & $* * *$ & 0.49 & \\
\hline 10 & SFO-enriched base & $* * *$ & 0.02 & NS & 0.0003 & NS & 0.31 & $* * *$ & 0.39 & $*$ & 0.70 & NS \\
\hline 11 & Milk fat-enriched base & NS & 0.0004 & NS & 0.03 & NS & 0.23 & NS & 0.23 & $* * *$ & 0.71 & \\
\hline 7 & Standard base & *** & 0.006 & NS & 0.13 & NS & 0.26 & *** & 0.36 & * & 0.79 & $* * *$ \\
\hline 12 & Sucrose-enriched base & NS & 0.0004 & $*$ & 0.15 & NS & 0.08 & NS & 0.05 & *** & 0.80 & \\
\hline 4 & Standard ONS & NS & 0.001 & $* *$ & 0.05 & $* * *$ & 0.34 & * & 0.12 & $*$ & 0.61 & NS \\
\hline 14 & Starch-enriched ONS & NS & 0.002 & NS & 0.001 & $*$ & 0.25 & $*$ & 0.20 & $*$ & 0.63 & \\
\hline
\end{tabular}

${ }^{1}$ Mean values from a 100-point unstructured line scale; mean values based on scores from 2 sessions.

${ }^{2} \mathrm{CaCas}=$ calcium caseinate; $\mathrm{NaCas}=$ sodium caseinate; $\mathrm{WPC}=$ whey protein concentrate; $\mathrm{ONS}=$ oral nutritional supplement; $\mathrm{MPC}=$ milk protein concentrate; $\mathrm{SFO}=$ sunflowe oil.

勇 ${ }^{3}$ Significance of difference as shown by repeated-measures ANOVA of sip results only: $0.1 \%$ confidence level $(* * *), 1 \%$ confidence level $(* *), 5 \%$ confidence level $(*)$, not significant

(NS). $\mathrm{R}^{2}$ values were calculated from linearity over time and include data from both sips and after-effects; therefore, some attributes may differ significantly between sips, but may

not have the strongest linear correlation (e.g., sweetness differed significantly between sips but did not have a linear increase over the complete consumption time). 


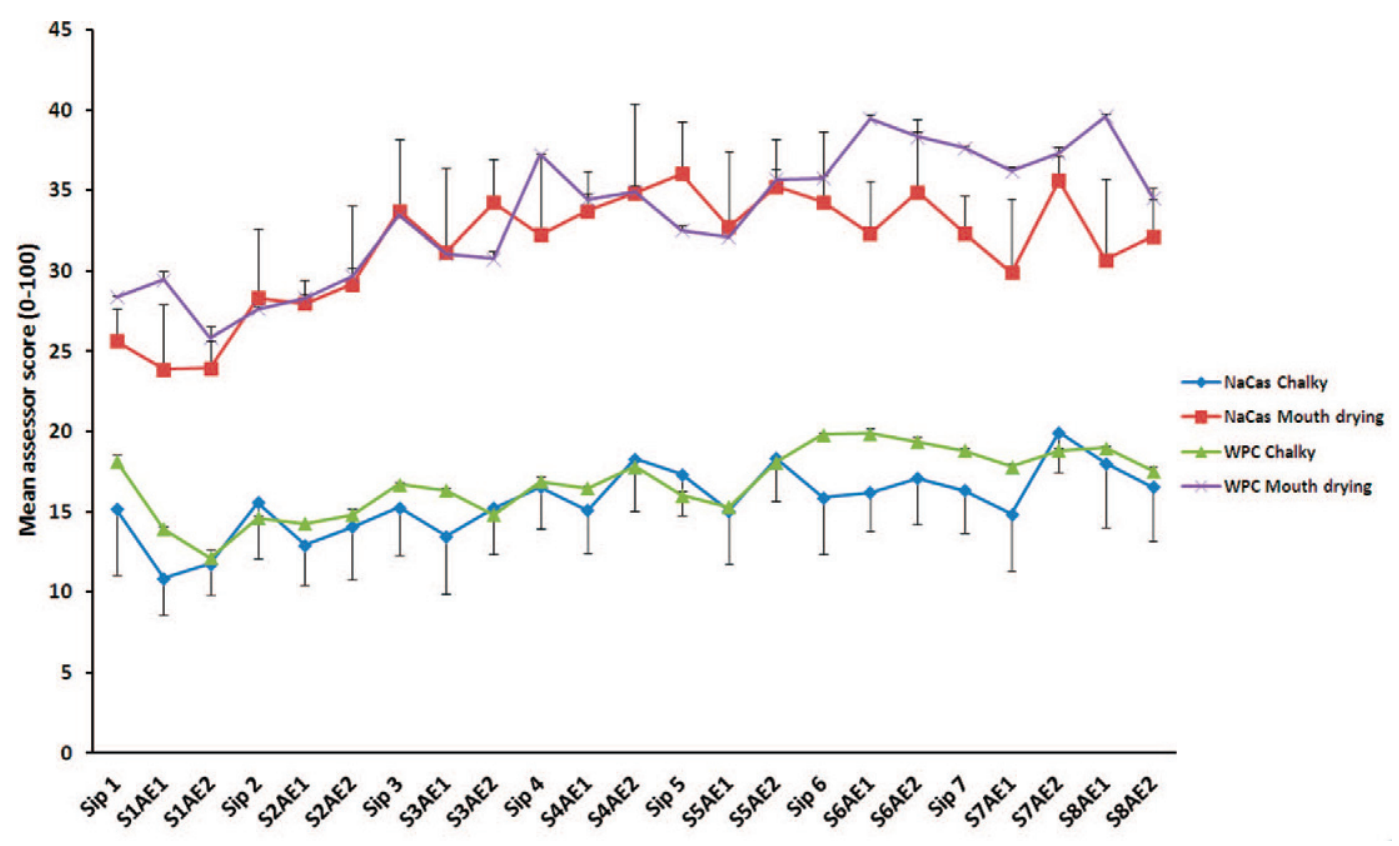

Figure 3. Sequential profile of mouth drying in 5\% whey protein concentrate (WPC) and $5 \%$ sodium caseinate (NaCas)-enriched milks. Values shown are assessor mean scores \pm SEM, with each numbered sip (Sip 1 to Sip 8) and corresponding after-effects (e.g., S1AE1 = sip 1 after-effect 1). Color version available in the online PDF.

that both led to a similar levels of mouth drying, the perception of which increased over repeat consumption in both cases. Investigating the role of other proteins, specifically WPC, may help to explain the overall level of mouth drying in full ONS products.

\section{Mouth Drying Comparison of Whey and Caseinate in Skim Milk}

Whey has previously been considered to be the source of mouth drying in beverages, particularly acidic drinks (Sano et al., 2005), through the precipitation of the protein within the oral cavity (Josephson et al., 1967; Sano et al., 2005), through interaction with salivary proteins (Beecher et al., 2008; Ye et al., 2011), or by binding of the whey protein to human buccal cells (Ye et al., 2012).

The current study compared the mouth drying of NaCas and WPC75-enriched skim milk, with both protein powders used at the same level of addition $(5 \%$ $\mathrm{wt} / \mathrm{wt}$ ), resulting in an overall protein concentration in the samples of 7.4 and $7.0 \%$ (wt/wt), respectively. The samples were balanced for viscosity with starch-based thickener $(0.4 \% \mathrm{wt} / \mathrm{wt})$ and for sweetness with lactose (Table 1, samples 2 and 3). Sequential profiling found that the WPC75 and NaCas samples were not significantly different for mouth drying or chalkiness (Figure 3). Mouth drying increased significantly $(P=0.001)$ over time, by $43 \%$ for WPC75 and by $35 \%$ for NaCas, with no significant increase in chalkiness.

The slight difference in sample protein contents, with the WPC75 sample having $0.5 \%$ less total protein, appeared to have a minimal effect on the drying or chalky nature of the samples. The profiles indicated a trend that mouth drying of WPC75 increased to a greater extent toward the end of repetitive consumption, compared with NaCas, although we observed no significant differences. The profiles might indicate a trend for whey to elicit a greater buildup of mouth drying than casein, if consumed at larger volumes (such as $200 \mathrm{~mL}$, the typical size of an ONS), and could be a cause of prolonged mouth drying using these dairy beverages. Further comparisons between the protein types of ONS are required to substantiate any role of WPC, compared with casein, in mouth drying of ONS.

\section{Role of MPC in Mouth Drying of ONS}

Another major protein ingredient of ONS is MPC (MPC85), which contains both casein (78\%) and whey $(22 \%)$ proteins in the same proportions as in milk. The concentrated milk protein forms the major protein base for typical ONS products (4.4\%) and, therefore, could be directly involved in the mouth-drying nature of these beverages. To assess the role of these proteins in the mouth drying of complete ONS beverages, 3 modi- 


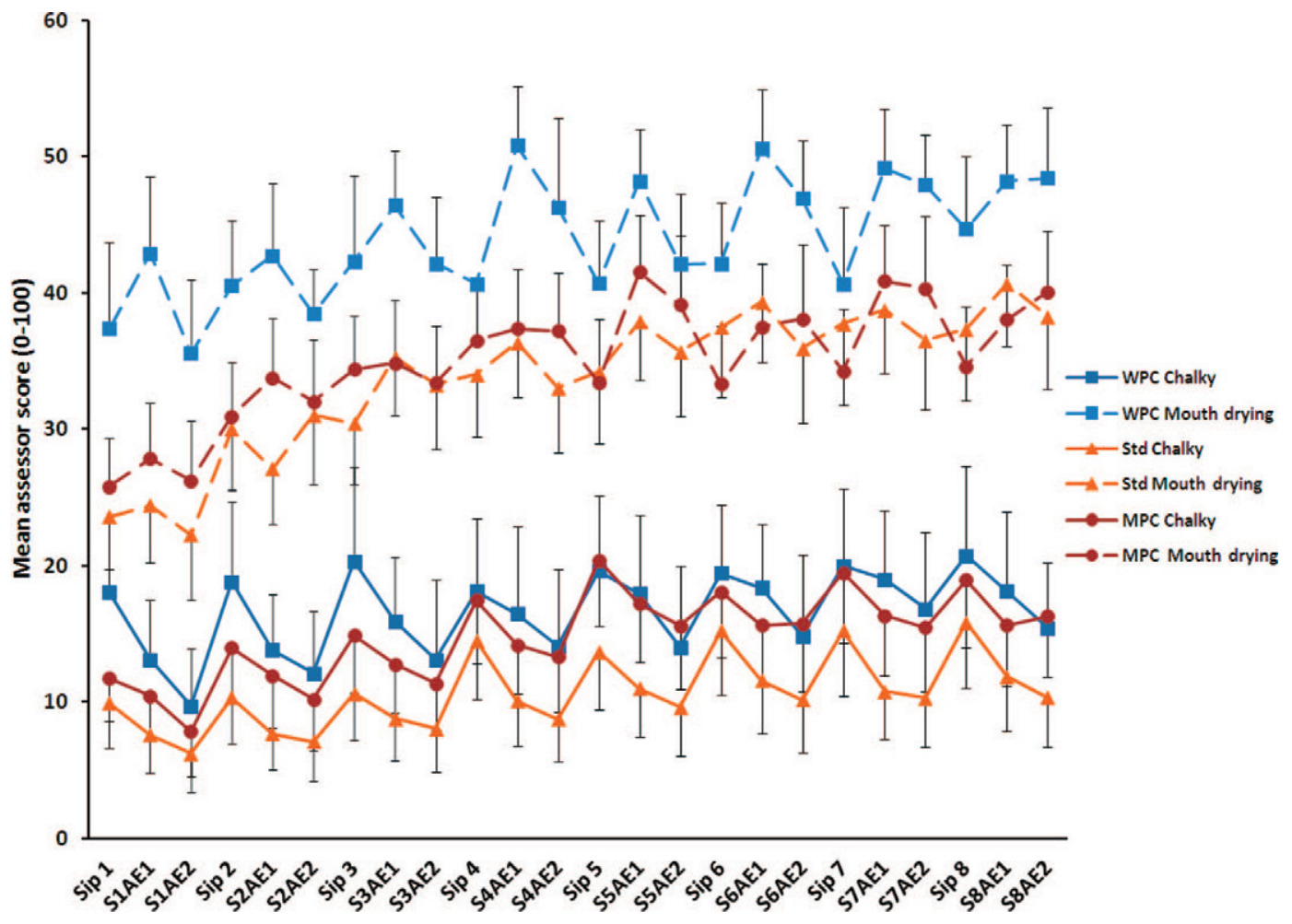

Figure 4. Mouth drying and chalkiness of standard (Std) unflavored oral nutritional supplement (ONS) and whey protein concentrate (WPC)- and milk protein concentrate (MPC)-enriched unflavored ONS sequential profiles. Values shown are assessor mean scores \pm SEM, with each numbered sip (Sip 1 to Sip 8) and corresponding after-effects (e.g., S1AE1 = sip 1 after-effect 1). Color version available in the online PDF.

fied ONS were sequentially profiled. An ONS enriched with WPC75, another with all total protein originating from MPC85, and a standard ONS were compared by the panel (Table 1, samples 4, 5, and 6). All 3 modified ONS were unflavored, and all were matched to the same $8.7 \%$ of total protein typical of ONS beverages.

Sequential profiling found the standard unflavored ONS increased in chalky $(P=0.006)$, mouth coating $(P<0.001)$, and mouth drying $(P<0.001)$ characteristics, whereas the WPC75-enriched ONS was not found to increase significantly in any attribute. However, the WPC75-enriched sample was substantially and significantly $(P<0.001)$ higher in mouth drying overall compared with the standard and MPC85-enriched ONS prototypes (Figure 4). The mouth drying and chalky profiles of MPC85-enriched and standard ONS were very similar over repeated consumption and, although both appeared to increase in mouth drying, the standard was the only sample to increase significantly over time. The levels of chalkiness in these samples, especially the protein-modified ONS samples, were high. This may be due to the modified proportions of proteins in these products, which may have affected their stability and protein hydration. However, the panel was trained and fully understood the different natures of chalky and mouth-drying characteristics; therefore, differences in mouth drying were considered separate from chalkiness changes with consumption.

This overall assessment of mouth drying in ONS and milk-based beverages, as conducted in this investigation, found both whey and casein to impart some mouth-drying characteristics. Generally, casein from both NaCas and MPC85 was found to elicit slightly less mouth-drying characteristics than whey from WPC85. Even though mouth drying is less severe from casein, these proteins still elicit some drying effects; therefore, casein may play a role in the overall drying perception of ONS. Paired comparison testing with older adults found that this cohort was able to detect mouth drying in dairy beverages and, in the case of rennet whey, to a greater extent than younger adults (Withers et al., 2013). Therefore, older adults not only perceive mouth drying, but can specifically detect whey-based mouth drying, and may be particularly sensitive to this attribute. This highlights the importance of minimizing protein-derived mouth drying to improve the enjoyment of ONS. Therefore, the potential factors to mask mouth drying were investigated through sequential profiling of simplified protein-enriched milk systems with additional masking ingredients. 


\section{Reduction of Mouth Drying in Protein-Enriched Milk Systems and ONS}

A protein-enriched skim milk system was developed as a mouth-drying base for all subsequent masking work. Milk protein concentrate with $85 \%$ protein and WPC75 were selected for this base as these elicited the highest levels of mouth-drying buildup in similar protein-enriched milks and ONS, and the base aimed to mimic the drying sensations elicited by ONS products.

Preliminary sequential profiling investigated the mouth-drying levels and buildup of 2 potential base samples, one with a WPC and MPC blend and one with MPC only (Table 1, samples 7 and 8). This aimed to establish a suitable mouth-drying base for subsequent drying reduction and masking analysis. The trained panel sequentially profiled MPC- and WPC-rich bases, with both samples eliciting some mouth drying and both being severely chalky (Figure 5).

Although MPC85 appeared to be the more mouth drying overall, we observed no significant difference between the bases in drying characteristics $(P=$ 0.12). The WPC75-enriched sample was found to be less mouth drying on initial sip; however, mouth drying increased significantly by $31 \%$ over the consump- tion period $(P=0.02)$, whereas the MPC85-enriched sample did not elicit a significant increase $(P=0.11)$. This finding could suggest a potential trend of WPC75 to increase in mouth drying with repeated consumption to a greater extent than the MPC85 used in this study, especially over consumption of larger volumes. The MPC85 sample was also significantly chalkier $(P$ $<0.001)$ than the WPC75 sample, potentially due to casein particulates, suggesting that the WPC-rich base would be more suitable as a mouth-drying base. Therefore, the WPC75 and MPC85 mixed base was selected for further drying reduction and masking analysis with sweetness, viscosity, and lipid parameters.

\section{Masking of Mouth Drying in Protein-Enriched Milk Systems and ONS}

To assess the ability of each masking agent to minimize mouth drying in the 8\% WPC75 and 3\% MPC 85 base, sequential profiling of the base was compared with a thickened sample, an SFO sample, a milk fat sample, and a sweetened sample. The thickened sample was enriched with $1.8 \%$ starch thickener (Table 1, sample 9), $2 \%$ sunflower oil was added to the SFO sample (Table 1, sample 10), $2 \%$ milk fat was added to the milk fat

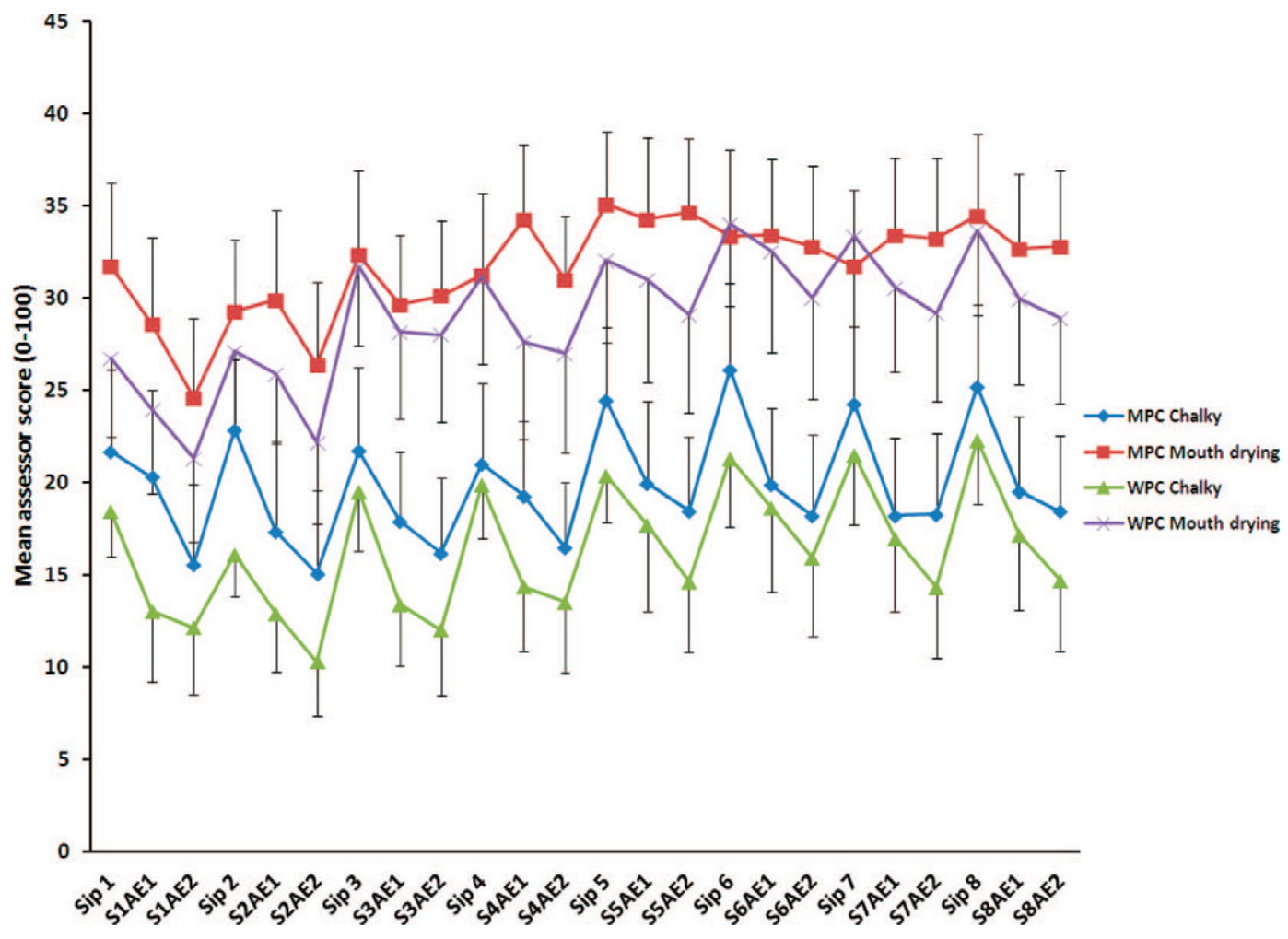

Figure 5. Sequential profile of mouth drying and chalkiness in whey protein concentrate (WPC)- and milk protein concentrate (MPC)enriched skim milks Values shown are assessor mean scores \pm SEM, with each numbered sip (Sip 1 to Sip 8) and corresponding after-effects (e.g., S1AE1 = sip 1 after-effect 1). Color version available in the online PDF. 


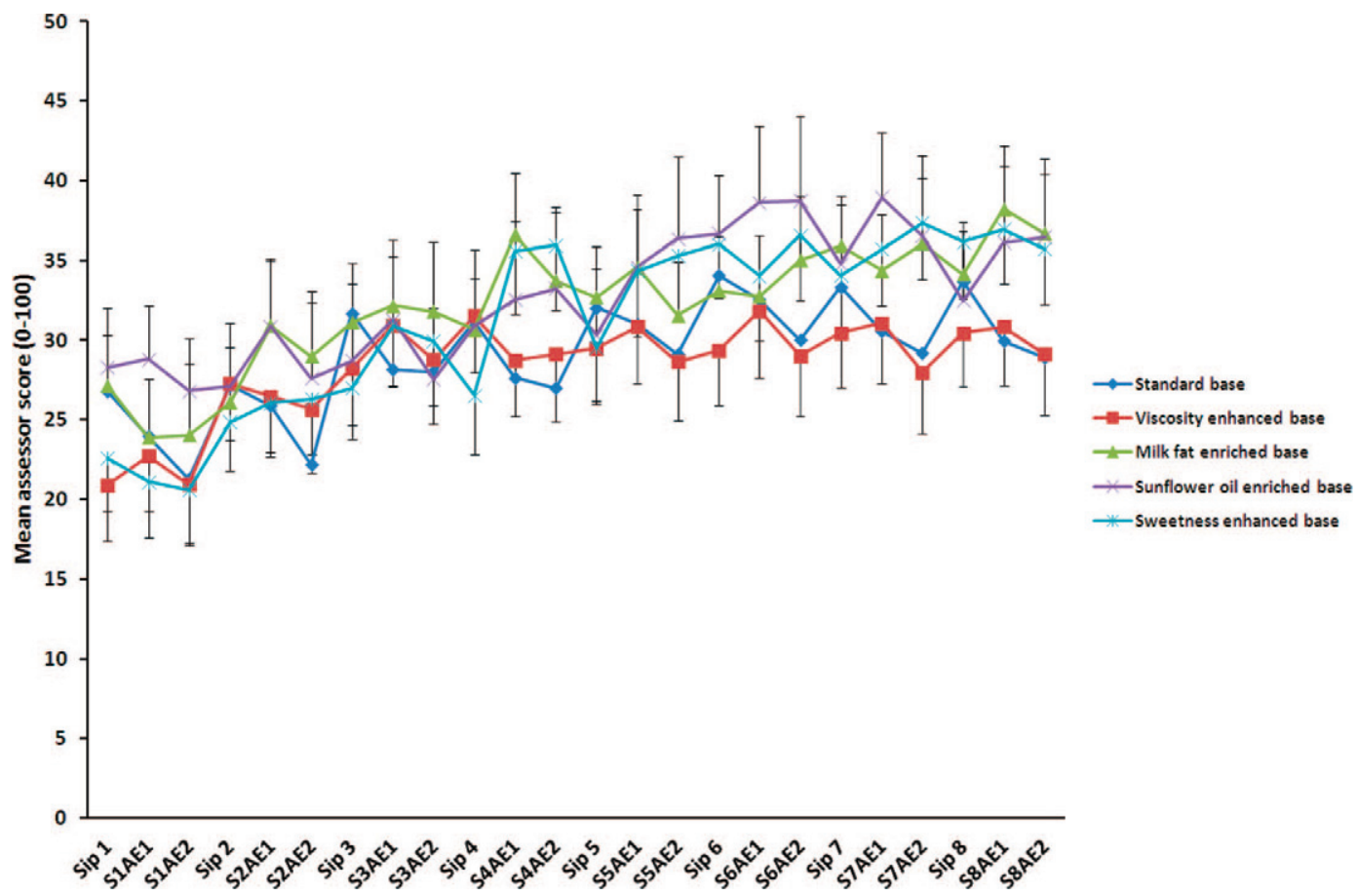

Figure 6. Sequential profile of mouth drying in whey protein concentrate (WPC)- and milk protein concentrate (MPC)-enriched skim milks with a range of masking agents, sweetness, viscosity, milk fat, and sunflower oil. Values shown are assessor mean scores \pm SEM, with each numbered sip (Sip 1 to Sip 8) and corresponding after-effects (e.g., S1AE1 = sip 1 after-effect 1). Color version available in the online PDF.

sample (Table 1, sample 11), and $3 \%$ sucrose was added to the base for the sweetened sample (Table 1, sample 12). The levels chosen were based on preliminary tasting tests (data not shown) that aimed to maximize the amount of the added ingredient without detrimental effects on other product attributes, hence avoiding products that were excessively and unpalatably thick, oily, or sweet. Sequential profiling of $40 \mathrm{~mL}$ of each sample indicated minimal differences between the samples in mouth-drying characteristics (Figure 6).

The similarity in mouth-drying ratings of the base and all masking samples suggests that the drying minimization methods employed, at the levels of the ingredients used here, did not reduce the drying characteristics of the protein-fortified skim milk. Repeatedmeasures ANOVA found no significant difference $(P=$ 0.20 ) overall between the mouth drying of all samples, further confirming the poor effectiveness of the masking methods on the reduction of mouth drying.

Assessing the individual profiles of the masking strategies, the sweetened base was significantly more mouth drying $(P<0.001)$ than the standard unsweetened base and increased over repeated consumption (Table 2 ). These findings suggest that increasing sweetness would not reduce the mouth drying of ONS beverages and limits the use of sweetness as a masking ingredient.

The SFO- and milk fat-enriched milk samples both increased significantly in mouth drying $(P=0.001)$ with repeated consumption, with no significant difference $(P=0.24)$ found between the samples. Both samples were significantly more mouth drying than the standard base with no added fat $(P<0.001)$. This suggests that the addition of lipid (at the $2 \% \mathrm{wt} / \mathrm{wt}$ level used) and the lipid type (within the 2 fat types used in this study) had no influence over the perceived mouth drying of the protein-enhanced milk systems; in fact, the addition of lipids increased the overall perceived mouth drying, albeit minimally. Regarding other attributes of the protein-enriched milks that were affected by lipid addition, mouth coating increased significantly over time $\left(P=0.001, \mathrm{R}^{2}=0.31\right.$, Table 2$)$ with the addition of $2 \%$ (wt/wt) SFO. This may have been a desirable effect if the intention was to increase lubrication within the mouth. However, milk fat (at $2 \%$ wt/wt) did not significantly affect mouth-coating perception. This may suggest that the unsaturated oil used in this study could enhance lubrication of ONS more than solid fats. Overall, these findings indicate that the use of lipids may be limited as masking agents for the minimization of mouth-drying characteristics in protein-enriched dairy systems.

The addition of the starch thickener $(1.8 \% \mathrm{wt} / \mathrm{wt})$ to the protein-enriched milk base increased the viscosity from $15.1 \pm 1.7$ to $42.8 \pm 3.1 \mathrm{mPa} \cdot \mathrm{s}$ at $44 \mathrm{~s}^{-1}$. Sequential profiling of standard and thickened base found a significant decrease in mouth drying by en- 


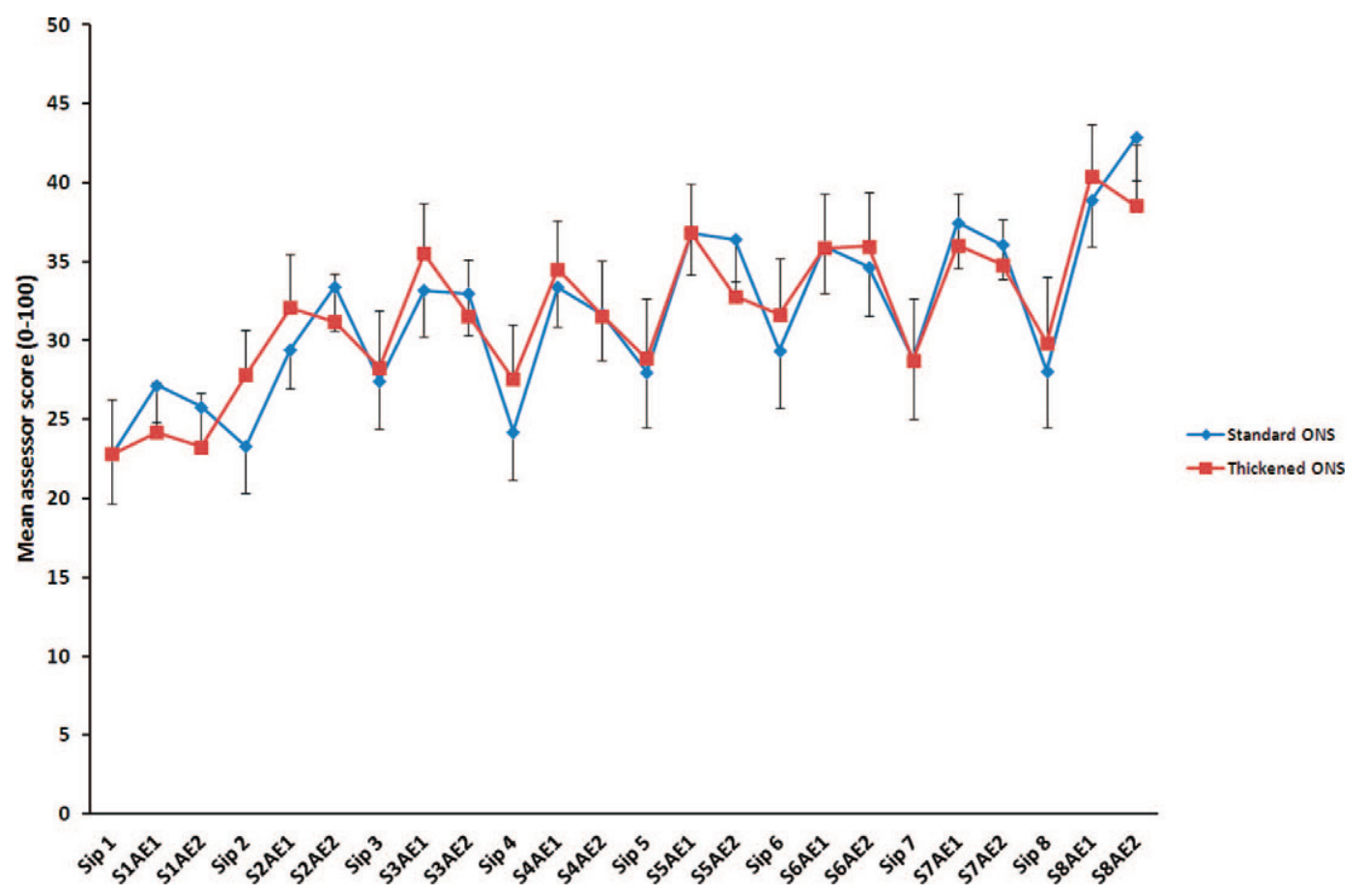

Figure 7. Sequential profile of mouth drying in standard and viscosity-enhanced oral nutritional supplement (ONS). Values shown are assessor mean scores \pm SEM, with each numbered sip (Sip 1 to Sip 8) and corresponding after-effects (e.g., S1AE1 = sip 1 after-effect 1 ). Color version available in the online PDF.

hancing the viscosity of the protein-enriched milk $(P=$ 0.01). Although the profiles are similar, the enhancedviscosity sample was lower for mouth drying through most of the sequential profile, especially toward the end of consumption period (Figure 6). Further analysis into the role of viscosity on the perception of mouth drying in full ONS beverages may help to clarify the role of this parameter to mask drying characteristics. Therefore, the viscosity of a complete ONS beverage enhanced with starch thickener $(1.8 \% \mathrm{wt} / \mathrm{wt})$ was compared with a standard ONS. This additional thickening agent increased the measured viscosity from $53.0 \pm 1.2$ to $135 \pm 6.0 \mathrm{mPa} \cdot \mathrm{s}$ at $44 \mathrm{~s}^{-1}$. The trained panel assessed both products for mouth drying (Figure 7), as well as sweetness, mouth coating, chalky, and metallic attributes (Table 2). No significant difference in mouth drying was found between the standard and viscosityenhanced ONS samples in the viscosity range assessed $(P=0.31)$. Thus, increasing the thickness of the sample with starch had no effect on the overall mouth drying of the ONS sample. The difference (reduction) in mouth drying between the standard and viscosity-enhanced base (Figure 6) was minimal, and did not occur in the complex complete ONS samples (Figure 7). This finding indicates that viscosity enhancement is also unsuitable for mouth-drying reduction in ONS.

\section{General Discussion}

Mouth drying is an attribute found to build substantially during the consumption of ONS dairy-based beverages, and it could originate from whey or casein sources (Josephson et al., 1967; Harwalkar, 1972; Methven et al., 2010). Gel electrophoresis of ONS indicated the presence of $\gamma$-CN; the level was not quantified but appeared to be low. However, as casein contributes the major milk protein proportion of ONS, the potential contribution of this protein to mouth drying was not disregarded and caseinate types were compared for drying capabilities.

Sodium and calcium caseinates were found to elicit mouth drying in model milk systems and full ONS, with the calcium derivative eliciting more drying during repeated consumption. In caseinate manufacture, calcium is removed during the acid precipitation, which causes the micellar structure to disintegrate. However, the final caseinates vary in structure depending on the alkali used to neutralize the curd. The use of $\mathrm{NaOH}$ to make NaCas results in a colloidal solution of caseinate molecules when hydrated, whereas the use of $\mathrm{CaOH}$ to make CaCas results in micelle-like aggregates that form an opaque solution when hydrated (DMV, 2011). However, Srinivasan et al. (1999) found that CaCas 
aggregates differ in protein structure and content from the natural micelle, containing higher levels of Casensitive $\alpha-\mathrm{CN}$ and minimal $\beta$ - and $\kappa-\mathrm{CN}$ (Srinivasan et al., 1999). These protein aggregates could explain the chalkiness perceived in both milk and ONS. Sodium caseinate solution contains substantially fewer protein aggregates compared with rehydrated CaCas (Srinivasan et al., 1999) and was indeed found to be significantly less chalky in the present study. This structural difference may also explain the higher extent of mouth drying elicited by CaCas than NaCas in enriched milk systems, and agrees with our findings of sequential profiling. Sodium caseinate is already used in ONS rather than CaCas; therefore, considering that this ingredient is lower in particulates and leads to less chalkiness and mouth drying and because we found little evidence of large quantities of $\gamma-\mathrm{CN}$ in the ONS, the focus of the study was directed toward whey as a cause of drying in these dairy-based beverages.

Whey-based dairy beverages have previously been found to be astringent, especially at reduced $\mathrm{pH}$, it being proposed that the negatively charged salivary proteins bind electrostatically to positively charged whey proteins to precipitate around the oral cavity (Sano et al., 2005; Ye et al., 2011) or bind to oral epithelial cells (Ye et al., 2012). This binding has typically been shown to occur most strongly at $\mathrm{pH} 5$, the isoelectric point of whey, when the acidic beverage mixes with neutral saliva (Demetriades et al., 1997; Sano et al., 2005). However, in milk and ONS, the $\mathrm{pH}$ range is almost neutral (6.5-7.2) and thus this mouth-drying mechanism is not applicable. The current study found WPC to elicit mouth-drying effects in both skim milk systems and full ONS; however, the exact mechanism of mouth drying in ONS remains unclear. Enrichment of ONS with either WPC75 or MPC85 to the same total protein content of $8.7 \%$ (wt/wt) resulted in whey and casein levels of $4.3: 4.4 \%$ and 1.7:7.0\%, respectively. The WPC-enriched ONS was substantially more mouth drying, implying that whey proteins may be the most important contributor to mouth drying in ONS. The second main aim of this study was to investigate methods to minimize the sensation.

Although reduction in perceived astringency of polyphenol-based beverages, such as wines, tea, and juice drinks, have previously been investigated (Josephson et al., 1967; Lyman and Green, 1990), few studies have analyzed the reduction of mouth drying of dairy beverages. Reducing astringency in red wine and tea has been studied thoroughly and has been managed through manipulation of sweetness and viscosity. These parameters were found to reduce astringency in polyphenol-rich red wine (Lyman and Green, 1990; Smith et al., 1996). The current study proposed the additional use of fat to minimize mouth drying by providing a fuller, richer mouthfeel and increased oral lubrication, as well as contributing to viscosity, all of which may mask mouth-drying perception (Christensen and Casper, 1987; Ship, 1999; Smith et al., 2006). Within whey protein beverages, one previous study focused on the effects of $\mathrm{pH}$ and viscosity on perceived astringency from a $6 \%$ protein (wt/vol) beverage (Beecher et al., 2008). They found that decreasing the $\mathrm{pH}$ from 6.8 to 3.4 led to a 7 -fold increase in astringency; however, within the current study, the aim was to reduce mouth drying at near-neutral $\mathrm{pH}$ rather than adjust $\mathrm{pH}$ as a treatment factor. In the previous study, increasing the viscosity almost 5 -fold (from 1.6 to $7.7 \mathrm{mPa} \cdot \mathrm{s}$ ) through the use of maltodextrin did not decrease perceived astringency (Beecher et al., 2008).

The present study used the methods for reduction of astringency in polyphenolics to determine whether they could also mask mouth drying generated by milk proteins (Smith et al., 1996; Smith and Noble, 1998) as well as re-investigating the effects of viscosity previously explored in whey protein beverages.

Increasing the viscosity of a protein-fortified sweetened milk matrix by 2.8 -fold (from 15 to $43 \mathrm{mPa} \cdot \mathrm{s}$ ) was found to significantly decrease perceived mouth drying, although the extent of difference was small. However, within the complete ONS beverage, increasing viscosity 2.5 -fold (from 53 to $135 \mathrm{mPa} \cdot \mathrm{s}$ ) did not reduce the perceived mouth drying. The mechanism behind the use of viscosity to reduce drying perception is uncertain. Potentially, astringent stimuli are unable to diffuse through highly viscous products to interact with mechanoreceptors in the oral cavity, thus reducing drying perception. However, this is unlikely because foods, especially beverages, are manipulated within the oral cavity during tasting and swallowing (Lyman and Green, 1990). Smith and Nobel (1998) suggested that astringency reduction is not possible above a threshold viscosity of $5 \mathrm{mPa} \cdot \mathrm{s}$, which was below the levels of all beverages analyzed in this study. Overall, we found that although viscosity may be able to reduce the perception of mouth drying to some extent at lower viscosity ranges (e.g., up to the $40 \mathrm{mPa} \cdot \mathrm{s}$ measured in the protein-fortified milk), it was not effective at the higher viscosities $(>50 \mathrm{mPa} \cdot \mathrm{s})$ of ONS beverages investigated in this case.

Sweetness, at the level of sucrose tested ( $3 \% \mathrm{wt} / \mathrm{wt})$, did not reduce mouth drying; in fact, it significantly increased the buildup of this attribute. A similar result was found when profiling a range of commercial ONS samples with the trained sensory panel, resulting in the sweetest sample being perceived as the most astringent (data not shown). Therefore, sweetness is not suitable for masking mouth drying in these dairy-based bever- 
ages. Smith et al. (1996) suggested that the addition of sucrose to red wine can influence viscosity sufficiently to reduce the astringent effect exclusively, negating the effect of sweetness entirely (Smith et al., 1996). However, the causes of astringency in red wine and mouth drying in ONS may be entirely different; therefore, this mechanism for reducing polyphenol astringency is clearly not suitable for dairy-based beverages.

Fat is an important contributor to the sensory attributes of milk beverages, affecting appearance, texture, and viscosity (Phillips et al., 1995). Fat can give creamy coating and viscous characteristics, as well as a greasy mouthfeel (Forde and Delahunty, 2002). The greasy, slippery mouthfeel of fat, as well as the potential tastes elicited by the FA composition, made lipids a possible option to mask ONS mouth drying. Initial informal tastings of protein-enriched milks suggested that milk fat was better than SFO at reducing mouth drying. However, sequential profiling with the trained panel found that an increase in lipid led to a minimal but significant increase in mouth drying, with no significant differences between fat types. This suggests that milk fat at the level used in this study ( $2 \% \mathrm{wt} / \mathrm{vol})$ was not suitable for masking mouth drying of proteinrich dairy beverages to the extent investigated in this study. It is noted, however, that others levels of oils or fats were not tested in this study, and that the study was limited by not using a homogenizer to incorporate the fat into the matrix. Previous studies found that fat could be used to help minimize astringency. In a recent paper, des Gachons et al. (2012) hypothesized that oral fatty sensation and astringency represented opposite sides of the sensory spectrum, with "slippery" at one end and "dry" and "rough" at the other, with astringent foods being thought to cleanse the mouth during a meal. However, their paper was based upon their study of "true" astringents such as catechins. In the current study, the lipid droplet size within the samples was not characterized or modified and yet, as highlighted in a review by van Vliet et al. (2009), particle size and oil droplet size can substantially influence the perception of solid, semi-solid, and liquid foods. van Vliet et al. (2009) commented that, with liquid foods, friction between the oral cavity and the food plays an important role in texture perception and that particle size and aggregates affect friction coefficients. They noted that where astringents cause the precipitation of proteins in the mouth, the precipitate reduces salivary viscosity, which in turn affects lubrication within the mouth. Concerning protein-stabilized emulsions, previous work has shown that milk homogenized with $3 \%$ fat once taken into the mouth and expectorated after 1 min contains "slimy structures" and loose aggregates, which were thought to affect lubrication (Van Aken et al., 2005). However, the similar level of fat in milk used in the present study was not found to influence mouth drying. We recommend that future studies investigate varying levels of fat homogenized into the proteinfortified matrix.

\section{CONCLUSIONS}

This study found that ONS mouth drying appears to originate predominantly from whey proteins, and that masking mouth drying is not a simple task. However, the potential for casein to contribute to mouth drying was also demonstrated. Whether casein-derived mouth drying is due to the presence of $\gamma-\mathrm{CN}$ remains unanswered, and further investigation, including the use of HPLC to quantify $\gamma$-CN in heat-treated, proteinfortified beverages over shelf life, is recommended. Sweetness (resulting from the addition of $3 \%$ sucrose) and the addition of $2 \%$ lipid (as either milk fat or SFO) were both found to significantly increase the mouth drying perceived, albeit to a minimal extent. The addition of a cold-soluble modified starch thickener $(1.8 \%$ wt/wt) was found to significantly decrease perceived mouth drying compared with the protein-fortified milk base, albeit minimally. However, the same addition of thickener to complete ONS, which caused a 2.5-fold increase in measured viscosity, had no significant effect on the perception of mouth drying. No previous research studies have considered other options, suggesting that the high protein density of ONS limits the use of masking agents to minimize mouth drying. Therefore, further investigation of potential mechanisms of action in dairy-based mouth drying is needed before alternative masking methods can be determined and evaluated.

\section{ACKNOWLEDGMENTS}

This research was supported by Nestec Ltd. (Vevey, Switzerland).

\section{REFERENCES}

ASTM (American Society for Testing and Materials). 2004. Standard definitions of terms relating to sensory evaluation of materials and products. Annual Book of ASTM Standards. ASTM, Philadelphia, PA.

Bajec, M. R., and G. J. Pickering. 2008. Astringency: Mechanisms and perception. Crit. Rev. Food Sci. Nutr. 48:858-875.

Beecher, J. W., M. A. Drake, P. J. Luck, and E. A. Foegeding. 2008. Factors regulating astringency of whey protein beverages. J. Dairy Sci. 91:2553-2560.

Chien, J. T., and H. E. Snyder. 1983. Detection and control of soy milk astringency. J. Food Sci. 48:438-440.

Christensen, C. M., and L. M. Casper. 1987. Oral and nonoral perception of solution viscosity. J. Food Sci. 52:445-447.

Demetriades, K., J. N. Coupland, and D. J. McClements. 1997. Physicochemical properties of whey protein-stabilized emulsions as affected by heating and ionic strength. J. Food Sci. 62:462-467. 
des Gachons, C. P., E. Mura, C. Speziale, C. J. Favreau, G. F. Dubreuil, and P. A. S. Breslin. 2012. Opponency of astringent and fat sensations. Curr. Biol. 22:R829-R830.

DMV. 2011. Caseinate: The incredible milk protein. DMV, Friesland Campina, the Netherlands. Accessed Sep. 12, 2013. http://www. nutritionhorizon.com/home/TechnicalPaperDownload.rails?path $=$ PkZtxYCc8vMXt4wCAlU0dA\%3D\%3D\&Document $=2$ YsDqXk TbrqSOq7hx2O1qdzsguPBKz7sRe53bCNVi2NOqfkTnFsDJTDg9 LfXFaLh\&Id=24\&Title=Caseinates\%20-\%20The\%20Incredible\% 20Milk\%20Protein.

Early, R. 1998. Technology of Dairy Products. 2nd ed. Blackie Academic and Professional, London, UK.

Farrell, H. M., R. Jimenez-Flores, G. T. Bleck, E. M. Brown, J. E. Butler, L. K. Creamer, C. L. Hicks, C. M. Hollar, K. F. Ng-KwaiHang, and H. E. Swaisgood. 2004. Nomenclature of the proteins of cows' milk - Sixth revision. J. Dairy Sci. 87:1641-1674.

Fillion, L., and D. Kilcast. 2001. Food texture and eating difficulties in the elderly. Food Indust. J. 4:27-33.

Forde, C. G., and C. M. Delahunty. 2002. Examination of chemical irritation and textural influence on food preferences in two age cohorts using complex food systems. Food Qual. Prefer. 13:571-581.

Gosney, M. 2003. Are we wasting our money on food supplements in elder care wards? J. Adv. Nurs. 43:275-280.

Gunstone, F. D. 2002. Vegetable oils in food technology: Composition, properties, and uses. Pages 101-116 in Chemistry and Technology of Oils and Fats. 2nd ed. Blackwell, Ames, IA.

Hagerman, A. E., and L. G. Butler. 1981. The specificity of proanthocyanidin-protein interactions. J. Biol. Chem. 256:4494-4497.

Harris, E. L. V., and S. Angal. 1989. Protein Purification Methods. Oxford University Press, Oxford, UK.

Harwalkar, V. R. 1972. Characterization of an astringent flavor fraction from Cheddar cheese. J. Dairy Sci. 55:735-741.

Harwalkar, V. R., H. Cholette, R. C. McKellar, and D. B. Emmons. 1993. Relationship between proteolysis and astringent off-flavor in milk. J. Dairy Sci. 76:2521-2527.

Ireland, P. A., S. Z. Dziedzic, and M. W. Kearsley. 1986. Saponin content of soya and some commercial soya products by means of high-performance liquid chromatography of the sapogenins. J. Sci. Food Agric. 37:694-698.

Jensen, R. G. 2002. The composition of bovine milk lipids: January 1995 to December 2000. J. Dairy Sci. 85:295-350.

Josephson, R. V., E. L. Thomas, C. V. Morr, and S. T. Coulter. 1967. Relation of heat-induced changes in protein-salt constituents to astringency in milk systems. J. Dairy Sci. 50:1376-1383.

Kelly, M., B. Vardhanabhuti, P. Luck, M. A. Drake, J. Osborne, and E. A. Foegeding. 2010. Role of protein concentration and proteinsaliva interactions in the astringency of whey proteins at low $\mathrm{pH}$. J. Dairy Sci. 93:1900-1909.

Kim, H. Y., and R. Jimenez-Flores. 1992. Two dimensional analysis of skim milk proteins using preparative isoelectric focusing followed by polyacrylamide gel electrophoresis. J. Food Biochem. $16: 307-321$.

Lemieux, L., and R. Simard. 1994. Astringency, a textural defect in dairy products. Lait 74:217-240.

Lyman, B. J., and B. G. Green. 1990. Oral astringency: Effects of repeated exposure and interactions with sweeteners. Chem. Senses 15:151-164.

Mattes, R. D. 2009a. Oral detection of short-, medium-, and longchain free fatty acids in humans. Chem. Senses 34:145-150.
Mattes, R. D. 2009b. Oral thresholds and suprathreshold intensity ratings for free fatty acids on 3 tongue sites in humans: Implications for transduction mechanisms. Chem. Senses 34:415-423.

Methven, L., K. Rahelu, N. Economou, L. Kinneavy, L. LadbrookeDavis, O. B. Kennedy, D. S. Mottram, and M. A. Gosney. 2010 The effect of consumption volume on profile and liking of oral nutritional supplements of varied sweetness: Sequential profiling and boredom tests. Food Qual. Prefer. 21:948-955.

NDDTF (National Dysphagia Diet Task Force). 2002. The national dysphagia diet: Standardization for optimal care. American Dietetic Association, Chicago, IL.

Phillips, L. G., M. L. McGiff, D. M. Barbano, and H. T. Lawless. 1995. The influence of fat on the sensory properties, viscosity, and color of low fat milk. J. Dairy Sci. 78:1258-1266.

Sano, H., T. Egashira, Y. Kinekawa, and N. Kitabatake. 2005. Astringency of bovine milk whey protein. J. Dairy Sci. 88:2312-2317.

Ship, J. A. 1999. The influence of aging on oral health and consequences for taste and smell. Physiol. Behav. 66:209-215.

Smith, A. K., H. June, and A. C. Noble. 1996. Effects of viscosity on the bitterness and astringency of grape seed tannin. Food Qual. Prefer. 7:161-166.

Smith, A. K., and A. C. Noble. 1998. Effects of increased viscosity on the sourness and astringency of aluminum sulfate and citric acid. Food Qual. Prefer. 9:139-144.

Smith, C. H., J. Logemann, W. Burghardt, S. Zecker, and A. Rademaker. 2006. Oral and oropharyngeal perceptions of fluid viscosity across the age span. Dysphagia 21:209-217.

Srinivasan, M., H. Singh, and P. A. Munro. 1999. Adsorption behaviour of sodium and calcium caseinates in oil-in-water emulsions. Int. Dairy J. 9:337-341.

Tremblay, L., M. F. Laporte, J. Leonil, D. Dupont, and P. Paquin. 2003. Quantification of proteins in milk and milk products. Pages 49-138 in Advanced Dairy Chemistry, Vol. 1: Proteins. 3rd ed. P. F. Fox and P. L. H McSweeney, ed. Springer, New York, NY.

Van Aken, G. A., M. H. Vingerhoeds, and E. H. A. De Hoog. 2005. Colloidal behaviour of food emulsions under oral conditions. Pages 356-366 in Food Colloids: Interactions, Microstructure and Processing. E. Dickinson, ed. The Royal Society of Chemistry, London, UK

van Vliet, T., G. A. van Aken, H. H. J. de Jongh, and R. J. Hamer. 2009. Colloidal aspects of texture perception. Adv. Colloid Interface Sci. 150:27-40.

Withers, C., M. Gosney, and L. Methven. 2013. Perception of thickness, mouth-coating and mouth-drying of dairy beverages by younger and older volunteers. J. Sens. Stud. 28:230-237. http:// dx.doi.org/10.1111/joss.12039.

Wood, F. W. 1968. Psychophysical studies on the consistency of liquid foods. Pages 40-49 in S.C.I. Monograph: Rheology and Texture of Foodstuffs. Society of Chemical Industry, London, UK.

Ye, A., C. Streicher, and H. Singh. 2011. Interactions between whey proteins and salivary proteins as related to astringency of whey protein beverages at low pH. J. Dairy Sci. 94:5842-5850.

Ye, A., T. Zheng, J. Z. Ye, and H. Singh. 2012. Potential role of the binding of whey proteins to human buccal cells on the perception of astringency in whey protein beverages. Physiol. Behav. 106:645-650. 